\title{
Ustandaryzowane dokumenty zawierające informacje o produkcie ubezpieczeniowym. Możliwe interpretacje w kontekście pojęcia produktu ubezpieczeniowego
}

Ustawa o dystrybucji ubezpieczeń nałożyła na dystrybutora ubezpieczeń wymóg przekazywania klientowi obiektywnych informacji o produkcie ubezpieczeniowym przed zawarciem umowy ubezpieczenia. W przypadku ubezpieczeń działu Il informacje te powinny być przekazywane w formie ustandaryzowanego dokumentu. Celem niniejszego artykułu jest analiza wybranych problemów praktycznych zwiqzanych ze stosowaniem przepisów o ustandaryzowanych dokumentach zawierajacych informacje o produkcie ubezpieczeniowym. Rozstrzygnięcie tych problemów będzie w istocie w dużej mierze pochodna rozstrzygnięcia, co kryje się pod pojęciem produktu ubezpieczeniowego. Niestety przepisy nie zawieraja definicji tego wyrażenia, co prowadzić może do wniosków niejednoznacznych w obszarach istotnych dla praktyki. Wartykule zostały omówione przede wszystkim główne watpliwości i możliwe sposoby interpretacji przepisów.

Słowa kluczowe: dystrybucja ubezpieczeń; ustandaryzowany dokument zawierający informacje o produkcie ubezpieczeniowym, IPID, produkt ubezpieczeniowy.

\section{Wprowadzenie}

Ustawa o dystrybucji ubezpieczeń ${ }^{1}$ (dalej: u.d.u.) nałożyła na dystrybutorów ubezpieczeń szereg nowych obowiązków. Jednym z nich jest przewidziany w art. 8 ust. 1 ustawy obowiązek podania klientowi przed zawarciem umowy ubezpieczenia lub umowy gwarancji ubezpieczeniowej²

1. Ustawa z dnia 15 grudnia 2017 r., Dz. U. 2018, poz. 2210, tekst jedn.

2. Przepisy u.d.u. dotyczące obowiązków dystrybutorów odnoszą się do obowiązków związanych zarówno z zawieraniem umów ubezpieczenia, jak i zawieraniem umów gwarancji ubezpieczeniowych. W artykule będę 
w zrozumiałej formie obiektywnych informacji o produkcie ubezpieczeniowym, w celu umożliwienia mu podjęcia świadomej decyzji. W odniesieniu do ubezpieczeń działu Il załącznika do ustawy o działalności ubezpieczeniowej i reasekuracyjnej ${ }^{3}$ (dalej: u.dz.u.r.) - czyli pozostałych ubezpieczeń osobowych oraz ubezpieczeń majątkowych - zgodnie z art. 8 ust. 4 u.d.u., informacje o produkcie ubezpieczeniowym sa przekazywane w postaci ustandaryzowanego dokumentu, sporządzanego przez twórcę produktu ubezpieczeniowego.

Niestety, treść przepisów dotyczących ustandaryzowanych dokumentów zawierających informacje o produkcie ubezpieczeniowym (dalej: IPID ${ }^{4}$ ) rodzi liczne watpliwości o bardzo istotnym znaczeniu dla praktyki. Watpliwości te dotyczą między innymi następujących (zresztą często powiązanych ze sobą) obszarów:

1) Czy IPID powinien odzwierciedlać treść umowy ubezpieczenia, będąca pochodną uzgodnień pomiędzy stronami, czy też tylko postanowienia wzorca umownego mającego zastosowanie do umowy?

2) Jaki podmiot w określonych sytuacjach może być uznany za twórcę produktu, a tym samym jest odpowiedzialny za opracowanie IPID (w szczególności przy dystrybucji w kanale brokerskim)?

3) Czy występują sytuacje, w których przekazanie IPID nie będzie konieczne?

4) Do czego powinien odnosić się IPID w przypadku ubezpieczeń „pakietowych” 5 (tj. jeden IPID do całego „pakietu” czy też osobne IPID do „składowych pakietu”]?

Dla rozstrzygnięcia problemów wymienionych powyżej (a także wạtpliwości o charakterze szczegółowym składających się na te problemy) kluczowe jest ustalenie znaczenia wyrażenia „produkt ubezpieczeniowy”, które to wyrażenie nie jest definiowane w przepisach odnoszacych się do IPID. Z uwagi na ramy objętościowe niniejszego artykułu nie będę poruszał w nim innych licznych problemów związanych z interpretacją przepisów, do których rozstrzygnięcia nie wystarczy ustalenie znaczenia pojęcia produktu ubezpieczeniowego ${ }^{6}$.

Uprzedzając bardziej szczegółowe rozważania na ten temat, w mojej opinii, w wielu obszarach istotnych z punktu widzenia praktyki regulacje mające zastosowanie do IPID nie pozwalają niestety na udzielenie jednoznacznych odpowiedzi na powstające pytania. Do obrony nadaja się, moim zdaniem, różne sposoby interpretacji - niejednokrotnie wzajemnie się wykluczające. Prowadzi to w ostatecznym rozrachunku do efektów sprzecznych z głównymi motywami, którymi kierował się ustawodawca, wprowadzając te regulacje. Jest to pochodną nie tylko słabej jakości przepisów, ale również wad dotyczących samych założeń, które legły u podstaw regulacji. Zagadnienia te poruszam w dalszych częściach artykułu.

odnosił się jedynie do zawierania umów ubezpieczenia, jednak poczynione rozważania mają zastosowanie również do zawierania umów gwarancji ubezpieczeniowych.

3. Ustawa z dnia 15 września 2015 r., Dz. U 2019, poz. 381, tekst jedn.

4. Skrót pochodzący z języka angielskiego - od insurance product information document. W niniejszym artykule skrót IPID jest używany zarówno w odniesieniu do liczby pojedynczej („ustandaryzowany dokument”), jak i mnogiej („ustandaryzowane dokumenty”).

5. Pojęcie to omawiane jest $w$ dalszej części artykułu.

6. Na temat innych problemów związanych z IPID zob. np. J. Nawracała, IPID-y, czyli o pseudostandaryzacji (cz. 1), „Miesięcznik Ubezpieczeniowy” 2018, nr 12, s. 33-35, idem, IPID-y, czyli o pseudostandaryzacji (cz. 2), „Miesięcznik Ubezpieczeniowy” 2019, nr 1, s. 51-53. 


\section{Regulacje mające zastosowanie do IPID}

Ustandaryzowanych dokumentów zawierających informacje o produkcie ubezpieczeniowym (ubezpieczeń działu II) dotyczą art. 8 ust. 4 do 6 u.d.u. Art. 8 ust. 4 przewiduje obowiązek stosowania IPID, art. 8 ust. 5 dotyczy formy IPID, natomiast art. 8 ust. 6 odnosi się do jego zawartości.

Ustawa o dystrybucji ubezpieczeń w obszarze przepisów odnoszących się do IPID stanowi wierne przeniesienie na grunt naszego ustawodawstwa zasad wynikających z Dyrektywy Parlamentu Europejskiego i Rady (UE) 2016/97 z dnia 20 stycznia 2016 roku w sprawie dystrybucji ubezpieczeń? (dalej: IDD). Art. 8 ust. 4 do 6 u.d.u. odzwierciedlają bowiem to, co wynika z art. 20 ust. 5 do 8 IDD. Dodatkowo jednak, art. 20 ust. 9 IDD stanowi podstawę prawną do wydania przez Komisję Europejską „wykonawczych standardów technicznych dotyczących ustandaryzowanego formatu prezentacji dokumentu zawierającego informacje o produkcie ubezpieczeniowym, określające szczegóły prezentacji informacji”. Zgodnie z tym przepisem opracowanie projektu tych wykonawczych standardów technicznych należy do EIOPA ${ }^{8}$.

W tym kontekście znaczenie prawne mają przepisy wydanego w oparciu o art. 20 ust. 9 IDD Rozporządzenia Wykonawczego Komisji (UE) 2017/1469 z dnia 11 sierpnia 2017 roku, ustanawiajacego ustandaryzowany format prezentacji dokumentu zawierającego informacje o produkcie ubezpieczeniowym $^{9}$ (dalej: Rozporządzenie IPID). Rozporządzenie to obowiązuje w polskim porzadku prawnym bezpośrednio. Zakresem jego regulacji są objęte kwestie związane z treścią IPID, a także z forma prezentacji tej treści. W praktyce przepisy Rozporządzenia IPID są na tyle szczegółowe, że właściwie niepotrzebne staje się posiłkowanie treścią art. 8 ust. 5 i 6 u.d.u. Odwołują się one zresztą do regulacji IDD (powtórzonych w u.d.u.), jednak przy okazji jednocześnie rozwijają oraz uszczegóławiaja zasady wynikające z tych regulacji.

Rozporządzenie IPID pod względem merytorycznym jest całkowicie oparte na dokumencie przygotowanym przez EIOPA (czyli projekcie, o którym mowa w art. 20 ust. 9 IDD) - Draft Implementing Technical Standards concerning a standardised presentation format for the Insurance Product Information Document of the Insurance Distribution Directive ${ }^{10}$. Ponadto EIOPA wydała dokument zatytułowany Final Report on Consultation Paper no. 16/007 on draft Implementing Technical Standards concerning a standardised presentation format for the Insurance Product Information Document of the Insurance Distribution Directive ${ }^{11}$. Ten drugi dokument ma charakter szczegółowego raportu z konsultacji rynkowych dokonywanych przez EIOPA na etapie tworzenia projektu standardów wykonawczych. W dokumencie tym zostały opisane różne kwestie o znaczeniu praktycznym, które EIOPA rozważała i konsultowała na tym etapie, a także wyjaśnienia

7. Dz.U.UE. L $26 \mathrm{z}$ dnia 2 lutego $2016 \mathrm{r}$.

8. European Insurance and Occupational Pensions Authority (Europejski Urząd Nadzoru Ubezpieczeń i Pracowniczych Programów Emerytalnych).

9. Dz.U.UE.L 209/19 z 12 sierpnia 2017 r.

10. Dokument $\mathrm{nr}$ EIOPA-17/056 z 7 lutego 2017 r.; dostępny pod adresem https://eiopa.europa.eu/Publications/ Technical\%20Standards/Draft\%20Implementing\%20Technical\%20Standards\%20on\%20the\%20Insurance\%20 Product\%20Information\%20Document.pdf [dostęp: 08.05.2019].

11. Dokument nr EIOPA_17/049 z 1 lutego 2017 r.; dostępny pod adresem https://eiopa.europa.eu/Pages/Consultations/EIOPA-CP-16-007-Consultation-Paper-on-the-proposal-for-the-Implementing-Technical-Standards-on-a-standardised-presentation-.aspx [dostęp: 08.05.2019]. 
dotyczące motywów przyjęcia określonych rozwiązań. Wyjaśnienia takie pojawiają się również w tekście Draft Implementing Technical Standards..., jednak są one mniej szczegółowe. W odróżnieniu od niektórych innych dokumentów wydawanych przez EIOPA ${ }^{12}$, żaden z dokumentów, o których mowa powyżej, nie ma charakteru wiążących wytycznych (o charakterze soft-law), adresowanych do organów krajowych (jak KNF) lub podmiotów rynku podlegających nadzorowi. Jednak Draft Implementing Technical Standards ... stanowi podstawę treści Rozporządzenia IPID wydanego przez Komisję i jest merytorycznie tożsamy z Rozporządzeniem IPID (różnice maja charakter jedynie techniczny). Z kolei zarówno Draft Implementing Technical Standards ..., jak i - w szerszym jeszcze zakresie - Final Report on Consultation Paper ... zawieraja opisy problemów rozważanych przez EIOPA przy tworzeniu projektu Rozporządzenia IPID. W tym kontekście można uznać, że mamy właściwie do czynienia ze źródłem, którym można się posiłkować przy dokonywaniu quasi-autentycznej wykładni przepisów Rozporządzenia IPID. Quasi - gdyż nie mamy do czynienia ze stanowiskiem prawodawcy (jest nim wszak Komisja), ale ze stanowiskiem podmiotu, który jest faktycznym autorem Rozporządzenia IPID. Nie jest to zatem wykładnia legalna, niemniej jednak można przyjąć, iż rzeczone dokumenty EIOPA będą miały bardzo duże znaczenie w praktyce jeśli chodzi o interpretację przepisów Rozporządzenia IPID ${ }^{13}$.

\section{Pojęcie produktu ubezpieczeniowego w świetle przepisów i poglądów doktryny}

Jak już wskazałem powyżej, próba zdefiniowania pojęcia produktu ubezpieczeniowego powinna stanowić punkt wyjścia do próby rozstrzygnięcia problemów praktycznych poruszonych w niniejszym artykule. Zanim jednak przejdę do rozważań szczegółowych, omówienia wymaga znaczenie tego pojęcia w świetle przepisów prawa i poglądów doktryny ${ }^{14}$.

\subsection{Pojęcie produktu ubezpieczeniowego w świetle przepisów}

Ani IDD, ani u.d.u. nie zawierają definicji produktu ubezpieczeniowego - pomimo faktu, że posługują się tym terminem nie tylko w kontekście przepisów dotyczących IPID, ale również przepisów dotyczących:

12. Chodzi o dokumenty wydawane przez EIOPA w oparciu 0 art. 9 ust. 2 oraz art. 16 ust. 1 Rozporządzenia Parlamentu Europejskiego i Rady (UE) nr 1094/2010 z dnia 24 listopada 2010 r. w sprawie ustanowienia Europejskiego Urzędu Nadzoru (Europejskiego Urzędu Nadzoru Ubezpieczeń i Pracowniczych Programów Emerytalnych], zmiany decyzji nr 716/2009/WE i uchylenia decyzji Komisji 2009/79/WE. Szerzej na ten temat zob. np. M. Więcko-Tułowiecka, ElOPA's Preparatory Guidelines on Product Oversight and Governance Arrangements by Insurance Undertakings and Insurance Distributors in the Context of Polish Recommendations on Product Management, „Prawo Asekuracyjne” 2018, nr 3, s. 32 i nast.

13. Jak się wydaje - w szczególności jeśli interpretacji takiej będzie dokonywał KNF.

14. Przedmiotem rozważań jest rozumienie tego pojęcia w kontekście regulacji prawnych odnoszących się do IPID. Regulacje te są stosunkowo nowe. W chwili obecnej trudno mówić o jakimkolwiek dorobku orzecznictwa (czy to sądów administracyjnych, czy to sądów cywilnych), które mogłoby stanowić wskazówkę co do tego, jak rozumieć produkt ubezpieczeniowy na gruncie przepisów dotyczących IPID. 
- pojęcia dystrybucji ubezpieczeń (art. 4 ust. 2 i art. 6 pkt 4 u.d.u.; art. 2 ust. 1 pkt 1 i art. 2 ust. 2 pkt d IDD);

- procesu zatwierdzania i przeglądu funkcjonowania produktu ubezpieczeniowego (art. 11 u.d.u.; art. 25 IDD);

- czynności dystrybucji związanych z doradztwem i udzieleniem rekomendacji (art. 32 ust. 1 pkt 4 u.d.u.; art. 20 ust. 1 akapit 3 IDD);

- monitorowania rynku przez organ nadzoru (art. 63 u.d.u., art. 1 ust. 5 IDD).

IDD posługuje się jednak terminem produkt ubezpieczeniowy również w tych przepisach, w odpowiednikach których u.d.u. odnosi się już do umowy ubezpieczenia - np. art. 17 ust. 3 IDD (odpowiednikiem jest art. 7 ust. 2 u.d.u.), art. 24 IDD (odpowiednikiem jest art. 10 u.d.u.) oraz art. 26 do 30 IDD (część kwestii regulowanych w tych przepisach IDD została uregulowana w art. 9 ust. 1 pkt 2 oraz art. 10 ust. 5 u.d.u.].

Ponadto IDD posługuje się terminem produkt ubezpieczeniowy zamiennie albo obok innych terminów. Przykładowo:

- W motywie 10 preambuły jest mowa o dystrybucji „umów ubezpieczeniowych, w tym ubezpieczeniowych produktów inwestycyjnych", co mogłoby sugerować, że pojęcie produktu ubezpieczeniowego jest równoznaczne z pojęciem umowy ubezpieczenia. Analogicznie - art. 2 ust. 1 pkt 17 IDD zawierający definicję „ubezpieczeniowego produktu inwestycyjnego" w ppkt b wyłącza z zakresu tej definicji pewne rodzaje „umów ubezpieczenia na życie”.

- Art. 19 ust. 1 pkt c IDD mówi o poradzie (doradztwie) w odniesieniu do „proponowanej umowy ubezpieczenia" ( co jest też zbieżne z terminologia użyta przy definicji doradztwa zawarta w art. 2 ust. 1 pkt 15 IDD). Analogicznie - art. 20 ust. 3 IDD również mówi o świadczeniu doradztwa „na podstawie wystarczającej liczby umów ubezpieczeń dostępnych na rynku” oraz o obowiazku przygotowania zindywidualizowanej rekomendacji w odniesieniu do „umowy ubezpieczenia”. Jednak z drugiej strony art. 20 ust. 1 akapit 3 IDD odnosi obowiązek udzielenia zindywidualizowanej rekomendacji do "danego produktu”. Natomiast art. 22 ust. 2 akapit 3 IDD stanowi, że Państwa Członkowskie moga wprowadzić obowiązek świadczenia doradztwa „w przypadku sprzedaży każdego produktu ubezpieczeniowego lub niektórych rodzajów produktów ubezpieczeniowych". Zdaje się to sugerować, że terminy produkt ubezpieczeniowy oraz umowa ubezpieczenia mogạ być używane zamiennie. Podobne zamieszanie terminologiczne występuje w motywie 47 preambuły IDD.

- Wart. 2 ust. 1 pkt 1 IDD (definicja dystrybucji ubezpieczeń) mowa jest przede wszystkim o różnych czynnościach związanych z „umowami ubezpieczenia”, jednak pojawia się także pojęcie produktów ubezpieczeniowych (w kontekście „opracowania rankingu produktów ubezpieczeniowych obejmującego porównanie cen i produktów" - tzw. porównywarki]. Mogłoby to sugerować, że jednak pojęcie umowy ubezpieczenia jest czymś innym niż pojęcie produktu ubezpieczeniowego (gdyż czynności dystrybucji dotyczą generalnie umów ubezpieczenia, a tylko dystrybucja przy użyciu tzw. porównywarek odnosi się do produktów).

- W motywie 9 preambuły jest mowa o „produktach i usługach ubezpieczeniowych”, co sugeruje, że produkt ubezpieczeniowy nie jest terminem tożsamym z usługq ubezpieczeniowq.

Żadnej definicji terminu produkt ubezpieczeniowy nie zawiera też Rozporządzenie IPID. Nie definiują tego pojęcia także wspomniane wcześniej dokumenty EIOPA związane z Rozporządzeniem IPID. Również inne powiązane z IDD regulacje, w których pojawia się termin produkt ubezpieczeniowy, nie zawierajajego definicji. Chodzi tutaj w szczególności o Rozporządzenie delegowane Komisji 
(UE) 2017/2358 z dnia 21 września 2017 roku uzupełniające dyrektywę Parlamentu Europejskiego i Rady (UE) 2016/9? w odniesieniu do wymogów w zakresie nadzoru nad produktem i zarządzania nim dla zakładów ubezpieczeń i dystrybutorów ubezpieczeń ${ }^{15}$ (dalej: Rozporządzenie 2017/2358), a także o dokumenty wydane przez ElOPA powiązane z kwestią regulowaną przez to rozporządzenie ${ }^{16}$.

Jeśli chodzi o regulacje niezwiązane „funkcjonalnie” z IDD, terminu produkt ubezpieczeniowy nie definiuje również u.dz.u.r., pomimo faktu, że się nim posługuje. Nadmienić jednak w tym miejscu należy, że zgodnie z art. 335 ust. 4 pkt 5 oraz ust. 5 pkt 2 u.dz.u.r. organ nadzoru może żądać m.in. „przedstawienia wzorców umownych, informacji o poszczególnych produktach ubezpieczeniowych oferowanych na podstawie indywidualnych negocjacji z ubezpieczającymi". Użycie takiego sformułowania mogłoby sugerować, że pojęcie produktu ubezpieczeniowego obejmuje również umowy ubezpieczenia indywidualnie wynegocjowane z ubezpieczającym. Terminu tego nie definiuje również Dyrektywa Wypłacalność $11^{17}$, której postanowienia u.dz.u.r. implementuje. Dyrektywa ta posługuje się zresztą tym terminem wyłącznie w preambule oraz w jednym przepisie "merytorycznym" (art. 206 ust. 2, w odniesieniu do obowiązku „zgłoszenia organom nadzoru podstaw technicznych obliczania składek przed wprowadzeniem produktu ubezpieczeniowego na rynek").

Termin produkt ubezpieczeniowy został z kolei zdefiniowany w następujących aktach prawnych i regulacjach soft-law:

- W $\S 2$ pkt 1 rozporządzenia Ministra Finansów z 2 listopada 2010 roku w sprawie zakresu informacji zawartych w rocznym raporcie o stanie portfela ubezpieczeń i reasekuracji zakładu ubezpieczeń. Produkt ubezpieczeniowy został zdefiniowany jako „typ umów ubezpieczenia, które zawierane są na podstawie tych samych ogólnych warunków ubezpieczenia”. Jednocześnie za dopuszczalne uznano uwzględnienie w ramach jednego produktu ubezpieczeniowego umów ubezpieczenia zawartych na podstawie różnych ogólnych warunków ubezpieczenia, pod warunkiem że zakres udzielonej ochrony ubezpieczeniowej oraz metody ustalania rezerw techniczno-ubezpieczeniowych sa identyczne lub prawie identyczne. Natomiast jako oddzielny produkt ubezpieczeniowy rozporządzenie traktowało wszystkie umowy ubezpieczenia z indywidualnie określonymi warunkami ubezpieczenia, jeśli nie zostały uwzględnione w ramach produktów związanych z ogólnymi warunkami ubezpieczenia.

- W $\S 2$ pkt 6 rozporządzenia Rady Ministrów z 22 marca 2011 roku w sprawie wyłączenia niektórych rodzajów porozumień, zawieranych między przedsiębiorcami prowadzącymi działalność

15. Dz.U.UE.L.2017.341.1 z dnia 20 grudnia 2017 r.

16. Czyli następujące dokumenty:

1) EIOPA-BoS-16-071, z dnia 18 marca 2016 r. - Preparatory Guidelines on product oversight and governance arrangements by insurance undertakings and insurance distributors;

2) EIOPA-BoS-16-071, z dnia 18 marca 2016 r. - Final Report on Public Consultation on Preparatory Guidelines on product oversight and governance arrangements by insurance undertakings and insurance distributors;

3) EIOPA-17/048, z dnia 1 lutego $2017 \mathrm{r}$. - Technical Advice on possible delegated acts concerning the Insurance Distribution Directive;

4) EIOPA-17/049, z dnia 1 lutego 2017 r. - Final Report on Consultation Paper no. 16/006 on Technical Advice on possible delegated acts concerning the Insurance Distribution Directive.

17. Dyrektywa Parlamentu Europejskiego i Rady 2009/138/WE z dnia 25 listopada 2009 r. w sprawie podejmowania i prowadzenia działalności ubezpieczeniowej i reasekuracyjnej (Wypłacalność II), Dz.U.UE.L.2009.335.1 $z$ dnia 17 grudnia $2009 \mathrm{r}$. 
Ustandaryzowane dokumenty zawierające informacje o produkcie ubezpieczeniowym...

ubezpieczeniową, spod zakazu porozumień ograniczających konkurencję ${ }^{18}$. Produkt ubezpieczeniowy został tu ujęty jako „usługa polegająca na udzielaniu, na podstawie umowy ubezpieczenia, ochrony na wypadek wystapienia zdarzenia losowego określonego w tej umowie".

- W Rekomendacjach dotyczących systemu zarządzania produktem ubezpieczeniowym wydanych przez KNF 22 marca 2016 roku produkt ${ }^{19}$ został zdefiniowany jako „projektowany / tworzony lub oferowany przez Zakład produkt rozumiany jako typ umów ubezpieczenia lub gwarancji ubezpieczeniowych, identyfikowanych przez odrębne warunki ubezpieczenia lub wewnętrzne oznaczenie stosowane w Zakładzie, zawieranych na podstawie tych samych wzorców umownych, dedykowanych temu produktowi (jeżeli specyfika danego produktu zakłada istnienie wzorca umownego]".

Należy jednak podkreślić w tym miejscu, że akty prawne wskazane w pkt 1 i 2 powyżej straciły moc obowiązująca. Natomiast Rekomendacje KNF wymienione w pkt 3 wprawdzie formalnie nadal obowiązuja, jednak powstaje pytanie, czy zachowuja w ogóle aktualność (a jeśli tak to w jakim zakresie) w kontekście tego, że w polskim porządku prawnym obowiązuje bezpośrednio stosowane, regulujące tę materię Rozporządzenie 2017/2358, które zostało wydane później niż Rekomendacje KNF²0.

Brak legalnej definicji terminu produkt ubezpieczeniowy nie oznacza jednak jeszcze, że treść przepisów oraz regulacji soft-law nie ma znaczenia przy ustalaniu zakresu pojęciowego tego wyrażenia. Pomocne przy rozstrzygnięciu, co należy rozumieć przez produkt ubezpieczeniowy, będą bowiem przepisy IDD oraz u.d.u., Rozporządzenia IPID, a także treść wspomnianych powyżej dokumentów EIOPA związanych z Rozporządzeniem IPID. Ponadto przydatne w tym kontekście będa przepisy Rozporządzenia 2017/2358²1. Kwestie te będę omawiał szczegółowo w rozdziale 3, analizując poszczególne problemy istotne z punktu widzenia praktyki.

\subsection{Pojęcie produktu ubezpieczeniowego $w$ świetle stanowiska doktryny}

Doktryna podejmowała liczne próby zdefiniowania terminu produkt ubezpieczeniowy - w tym również w kontekście przepisów IDD oraz u.d.u. (przede wszystkim w kontekście systemu zarządzania

18. Co ciekawe, regulujące analogiczną materię Rozporządzenie Komisji Europejskiej nr 267/2010r. z dnia 24 marca 2010 r. w sprawie stosowania art. 101 ust. 3 Traktatu o funkcjonowaniu Unii Europejskiej do niektórych kategorii porozumień, decyzji i praktyk uzgodnionych w sektorze ubezpieczeniowym (Dz.U.UE L 83/1 z dnia 30 marca 2010 r. ), pomimo że posługiwało się terminem „produkt ubezpieczeniowy”, to nie definiowało go.

19. Pomimo faktu, że Rekomendacje posługują się terminem produkt, to nie ma wạtpliwości co do tego, że chodzi o produkt ubezpieczeniowy.

20. Rekomendacje KNF stanowiły przeniesienie na nasz grunt krajowy wytycznych wydanych przez EIOPA (EIOPA-BoS-16-071, z dnia 18 marca 2016 r. - Preparatory Guidelines on product oversight and governance arrangements by insurance undertakings and insurance distributors] i sa z nimi w pełni spójne - szerzej na ten temat Więcko-Tułowiecka M., op. cit. Tymczasem, jak się wskazuje w literaturze przedmiotu wytyczne EIOPA „w znakomitej większości zostały skonsumowane w treści Rozporządzenia Delegowanego Komisji (UE) 2017/2358" (Mrozowska-Bartkiewicz B., Wnęk A., Pojęcie twórcy produktu ubezpieczeniowego w ustawie o dystrybucji ubezpieczeń, [w:] Insurance Challenges of Anno Domini 2018, Malinowska K., Tarsiuk A. [red.], AIDA, Warszawa 2018, s. 7?], z którym to stwierdzeniem w zupełności się zgadzam.

21. Dla celów dalszych rozważań wystarczające będzie odniesienie się wyłącznie do treści Rozporządzenia 2017/2358. Z tego względu pomijam rozważania na gruncie dokumentów ElOPA związanych z tym rozporzadzeniem, o których mowa w przypisie nr 1 ?. 
produktem, ale również w kontekście IPID). Zaproponowane sposoby zdefiniowania tego pojęcia są bardzo różne ${ }^{22}$. Można je podzielić zasadniczo na dwie grupy (abstrahując od innych różnic w stanowiskach prezentowanych przez poszczególnych autorów):

1) poglądy utożsamiające produkt ubezpieczeniowy z umową ubezpieczenia;

2) poglądy utożsamiające produkt ubezpieczeniowy z określonym typem umów ubezpieczenia, bez uwzględniania indywidualnych ustaleń, które zapadaja przy zawieraniu konkretnej umowy ubezpieczenia.

Różnicę pomiędzy tymi dwoma stanowiskami można ( $w$ pewnym uproszczeniu ${ }^{23}$ ) opisać $w$ ten sposób, że autorzy reprezentujący pierwszy pogląd w pojęciu produktu uwzględniają całą treść umowy ubezpieczenia, natomiast autorzy reprezentujący pogląd drugi - tylko treść ogólnych warunków ubezpieczenia $[\mathrm{OWU}]^{24}$. Utożsamianie produktu ubezpieczeniowego z umową ubezpieczenia oznacza, że elementem produktu ubezpieczeniowego stają się indywidualne ustalenia stron, takie jak np. wysokość składki ubezpieczeniowej, określony termin płatności, okres ubezpieczenia (oznaczony przez wskazanie dat), wybór konkretnego wariantu lub zakresu ubezpieczenia etc. Z kolei utożsamianie produktu ubezpieczeniowego z OWU²5 oznacza, że chodzi o ogół postanowień kształtujących prawa i obowiązki stron oraz zakres ubezpieczenia, jednak w sposób „niespersonalizowany" - a zatem wyznaczający jedynie ramy, w których może być udzielona ochrona ubezpieczeniowa. Opowiedzenie się za jednym z tych dwóch stanowisk pociagga za sobą daleko idące konsekwencje praktyczne, związane z kwestiami poruszanymi w rozdziale 3 niniejszego artykułu.

Do grona autorów reprezentujących pierwsze z opisanych stanowisk można zaliczyć np. Michała Ziemiaka ${ }^{26}$. Wskazuje się czasem tutaj również Katarzynę Malinowską ${ }^{27}$, jednak - jak się wydaje - błędnie ${ }^{28}$. Jako uzasadnienie tego stanowiska przytacza się przede wszystkim przepisy IDD,

22. W szczególności w ujęciu produktu ubezpieczeniowego wyłącznie w kontekście cywilnoprawnym (jako postanowienia określające prawa i obowiązki stron, zakres ochrony ubezpieczeniowej etc.) oraz w kontekście szerszym (aspekt ekonomiczny, marketingowy, aktuarialny etc.). W niniejszym artykule nie będę jednak omawiał szerokiego rozumienia pojęcia produktu ubezpieczeniowego, gdyż nie ma to większego znaczenia na gruncie poczynionych tu rozważań.

23. W uproszczeniu - ponieważ nie wszyscy przedstawiciele doktryny pod pojęciem produktu ubezpieczeniowego rozumieja wyłącznie postanowienia określające prawa i obowiązki stron umowy ubezpieczenia (ale np. również system taryf, procedury etc.).

24. Chodzi zresztą nie tylko o OWU, ale również o każdy inny wzorzec umowny w rozumieniu art. 384 k.c. (w praktyce ubezpieczeniowej spotyka się np. takie nazwy, jak szczególne warunki ubezpieczenia), a także każdy „szablon” umowy ubezpieczenia bądź klauzule i postanowienia dodatkowe, które mają (lub mogą mieć) standardowo zastosowanie do danego rodzaju umów ubezpieczenia.

25. Lub innymi wzorcami i szablonami, o których mowa w przypisie powyżej.

26. M. Ziemiak, Informacja o produkcie ubezpieczeniowym i tzw. karta informacyjna produktu. Kilka uwag na tle artykułów 8 i 9 ustawy o dystrybucji ubezpieczeń, [w:] Insurance Challenges of Anno Domini 2018, [red.] K. Malinowska, A. Tarsiuk, AIDA, Warszawa 2018, s. 9 ?.

27. Na stanowisko K. Malinowskiej powołuje się M. Ziemiak, op. cit. Z kolei A. Przybysz i T. Kwieciński wskazuja, że stanowisko K. Malinowskiej jest nie w pełni jasne [zob. A. Przybysz, T. Kwieciński, [w:] Nowe zasady dystrybucji ubezpieczeń. Zagadnienia prawne, [red.] J. Pokrzywniak, Wolters Kluwer, Warszawa 2018, publ. elektroniczna LEX, Rozdział 8.1., przypis nr 10).

28. K. Malinowska pisze wprawdzie: „Najnowsze uregulowania Dyrektywy IDD, choć posługuja się pojęciem produktu ubezpieczeniowego, nie wprowadzaja jego definicji. Niemniej jednak kontekst, w jakim to czynia, wskazuje na utożsamianie pojęcia produktu ubezpieczeniowego z umową ubezpieczenia." (K. Malinowska, Pojęcie zarzqdzania produktem ubezpieczeniowym w świetle dyrektywy o dystrybucji ubezpieczeń i prze- 
które rzekomo pozwalaja przyjać tożsamość pojęć produktu ubezpieczeniowego oraz umowy ubezpieczenia (m.in. opisywany przeze mnie powyżej motyw 10 preambuły IDD oraz definicję ubezpieczeniowego produktu inwestycyjnego ${ }^{29}$.

Pogląd prezentowany przez druga grupę autorów można uznać za dominujący. Do tej grupy można zaliczyć np. Julitę Nowak ${ }^{30}$, Marcina Orlickiego ${ }^{31}$, Jakuba Ziembę ${ }^{32}$, Aleksandrę Przybysz oraz Tomasza Kwiecińskiego ${ }^{33}$, Annę Urbańczyk ${ }^{34}$, Beatę Mrozowską-Bartkiewicz oraz Aldonę Wnęk ${ }^{35}$ a także Dorotę Maśniak ${ }^{36}$. Przedstawiane są różne argumenty przemawiające za takim podejściem. Przede wszystkim wskazuje się na:

- treść Rekomendacji KNF dotyczących systemu zarządzania produktem ubezpieczeniowym, które za produkt uznaja „typ umów ubezpieczenia”37;

- treść art. 11 u.d.u. dotyczącego systemu zarządzania produktem, w świetle którego produkt to coś powtarzalnego, a proces zatwierdzania produktu ubezpieczeniowego odnosić się może siłą rzeczy do pewnego typu umów, a nie do każdej umowy ubezpieczenia indywidualnie ${ }^{38}$;

- fakt, że u.d.u. odnosi obowiązek przekazania informacji do produktu ubezpieczeniowego, nie zaś do umowy ubezpieczenia ${ }^{39}$, a także porównanie treści przepisów u.d.u. z treścią pierwotnego

pisów implementacyjnych, „Wiadomości Ubezpieczeniowe” 2017, nr 1, s. 10). Jednak z drugiej strony, w tym samym artykule K. Malinowska stwierdza, że produkt ubezpieczeniowy można utożsamiać z ogólnymi warunkami ubezpieczenia (s. 11). Jak się zatem wydaje, rozważania tej Autorki dotyczące możliwości utożsamiania pojęcia produktu i umowy ubezpieczenia należy rozpatrywać raczej jako położenie akcentu na „sferę cywilnoprawną" pojęcia produktu ubezpieczeniowego. Natomiast nie można z nich wyciągać wniosku, jakoby produkt ubezpieczeniowy obejmował swym zakresem pojęciowym również indywidualne ustalenia umowne. Wniosek co do takiej interpretacji wydają się potwierdzać wywody tej Autorki zawarte w innym artykule (współautorstwa D. Maśniak), gdzie wskazuje ona na duże niejasności co do tego, czy na tle przepisów produkt ubezpieczeniowy można utożsamiać z umową ubezpieczenia. (D. Maśniak, K. Malinowska, Czynności dystrybucyjne w nowym reżimie zawierania umów ubezpieczenia - wybrane aspekty implementacji dyrektywy nr 2016/97 w sprawie dystrybucji ubezpieczeń, „Prawo Asekuracyjne” 2017, nr 2, s. 24-25).

29. Tak właśnie M. Ziemiak ([w: ] M. Ziemiak, op. cit. ), powołując się na rozważania K. Malinowskiej (zob. jednak uwagi w przypisie powyżej odnośnie do stanowiska K. Malinowskiej].

30. J. Nowak, [w]: Ustawa o dystrybucji ubezpieczeń. Komentarz, [red.] P. Czublun, CH Beck, Warszawa 2018, publ. elektroniczna LEGALIS, komentarz do art. 8 ustawy, pkt 55.

31. M. Orlicki, Ustandaryzowany dokument według ustawy o dystrybucji ubezpieczeń - zasady tworzenia i znaczenie prawne, „Prawo Asekuracyjne” 2017, nr 4, s. 16 i 19.

32. J. Ziemba, [w]: Ustawa o dystrybucji ubezpieczeń. Komentarz, [red.] P. Machulak, J. Ziemba, CH Beck, Warszawa 2018, publ. elektroniczna LEGALIS, komentarz do art. 8 ustawy, pkt 18.

33. A. Przybysz, T. Kwieciński, op. cit.

34. A. Urbańczyk, [w]: Nowe zasady..., Rozdział 6.6.

35. B. Mrozowska-Bartkiewicz, A. Wnęk, Pojęcie twórcy produktu ubezpieczeniowego w ustawie o dystrybucji ubezpieczeń, [w:] Insurance Challenges.., s. 83.

36. D. Maśniak, Czy test wymagań i potrzeb klienta to wniosek ubezpieczeniowy?, [w:] Dystrybucja usług ubezpieczeniowych, [red.] B. Gnela, M. Szaraniec, Difin, Warszawa 2017 s. 39-40.

37. Tak M. Orlicki, op. cit., s. 16; A. Przybysz, T. Kwieciński, op. cit.

38. Tak A. Przybysz, T. Kwieciński, op. cit. Również M. Orlicki bierze pod uwagę ten przepis jako punkt wyjścia, jednak swoje konkluzje zdaje się opierać bardziej na treści Rekomendacji KNF (M. Orlicki, op. cit.).

39. Tak A. Urbańczyk, op. cit. 
projektu ustawy o dystrybucji ubezpieczeń, który przewidywał obowiązek przekazywania informacji nie o produkcie ubezpieczeniowym, a o umowie ubezpieczenia ${ }^{40}$.

Pogląd utożsamiający pojęcie produktu ubezpieczeniowego oraz umowy ubezpieczenia nie może być uznany za słuszny. Nie przekonuja przywoływane tutaj argumenty w postaci rzekomego utożsamiania tych pojęć przez przepisy IDD. Przepisy, w których pojęcia te używane są obok siebie lub rzekomo zamiennie, są bowiem stosunkowo nieliczne, a ich treść nie wskazuje jednoznacznie na intencję ustawodawcy, zgodnie z która pojęcia te mają być tożsame. Jak się wydaje - współwystępowanie tych pojęć jest raczej przejawem niekonsekwencji ustawodawcy oraz braku głębszych przemyśleń co do tego, jakie znaczenie nadać używanym w IDD zwrotom (co zreszta znajduje potwierdzenie w samym fakcie, że zwroty te nie są definiowane). Mankamenty regulacji IDD w kontekście używanej siatki pojęciowej były już opisywane przez doktrynę ${ }^{41}$. Utożsamianie tych pojęć byłoby zresztą sprzeczne z zakazem dokonywania wykładni synonimicznej. Ponadto, przeciwko temu stanowisku przemawiaja argumenty za stanowiskiem prezentowanym przez druga grupę autorów, które omawiam poniżej. Krótkiego komentarza wymaga jednak w tym miejscu treść art. 335 ust. 4 pkt 5 oraz ust. 5 pkt 2 u.dz.u.r., zgodnie z którymi organ nadzoru może żądać m.in. „przedstawienia wzorców umownych, informacji o poszczególnych produktach ubezpieczeniowych oferowanych na podstawie indywidualnych negocjacji z ubezpieczającymi" ${ }^{42}$. Treść tego przepisu nie może w mojej opinii przemawiać za uznaniem, że przez produkt ubezpieczeniowy należy rozumieć treść umowy ubezpieczenia w kształcie indywidualnie wynegocjowanym - przynajmniej w kontekście przepisów dotyczących IPID. Po pierwsze - regulacja ta nie jest w żaden sposób funkcjonalnie powiązana z IDD. Po drugie - przepis ten nie stanowi również implementacji normy wynikającej z przepisów Dyrektywy Solvency II, zatem nie może być podstawą do oceny, w jaki sposób pojęcie produktu ubezpieczeniowego jest rozumiane przez ustawodawcę europejskiego. Paradoksalnie najsilniejszym argumentem za koniecznością utożsamiania produktu ubezpieczeniowego z treścią konkretnej umowy ubezpieczenia jest brzmienie niektórych przepisów IDD oraz u.d.u. dotyczących IPID, przytaczanych w podrozdziale 3.1 niniejszego artykułu. Argumenty te jednak nie moga w mojej ocenie przeważyć na korzyść omawianego tu stanowiska, z uwagi na szereg kontrargumentów omawianych przeze mnie poniżej.

Za prawidłowy uważam zatem pogląd, zgodnie z którym produkt ubezpieczeniowy to określony typ umów ubezpieczenia (bez uwzględniania indywidualnych ustaleń stron). Niemniej jednak niektórych ze wskazanych powyżej argumentów prezentowanych przez doktrynę nie można uznać za do końca przekonujące. I tak:

- Jeśli chodzi o Rekomendacje KNF dotyczące systemu zarządzania produktem ubezpieczeniowym, to są one jedynie regulacją soft-law i zostały wydane przez nasz krajowy organ nadzoru jeszcze przed uchwaleniem u.d.u. Wydaje się zatem, że nie mogą one stanowić podstawy do wykładni tego pojęcia.

40. Tak J. Nowak, op. cit., pkt 55; M. Orlicki, op. cit., s. 16.

41. Zob. np. Ł. Kamiński, Pojęcie usługi i produktu w dystrybucji usług ubezpieczeniowych, [w:] Dystrybucja usług ..., s. 273-281. Autor ten w sposób krytyczny omawia kwestię przemiennego stosowania przez ustawodawcę europejskiego pojęć produktu i usługi, dochodząc do konkluzji, że przyjęte rozwiązania sugeruja brak racjonalności ustawodawcy.

42. Jak się wydaje, treść tego przepisu nie była jednak dotąd przywoływana jako argument w dotychczasowych rozważaniach doktryny. 
- Jeśli chodzi o argument odnoszący się do regulacji u.d.u. / IDD dotyczących systemu zarządzania produktem, to wydaje się on przekonujący. Jednak z drugiej strony można postawić pytanie czy pojęcie produktu ubezpieczeniowego należy rozumieć identycznie w kontekście przepisów dotyczạcych obowiązków informacyjnych względem klienta oraz przepisów regulujących proces tworzenia i dystrybucji produktu przez twórców produktu i dystrybutorów. Mamy tutaj wszak do czynienia z dwoma różnymi obszarami. Mimo wszystko stoję na stanowisku, że można przyjać, iż taka tożsamość zakresu znaczeniowego faktycznie występuje. 0 ile bowiem można mieć zastrzeżenia co do racjonalności ustawodawcy europejskiego jeśli chodzi o konsekwencję w posługiwaniu się różnymi wyrażeniami (produkt ubezpieczeniowy, umowa ubezpieczenia, usługa ubezpieczeniowa, ubezpieczenie), o tyle jednak - zgodnie z zakazem wykładni homonimicznej - temu samemu terminowi (produkt ubezpieczeniowy) użytemu w tym samym akcie prawnym należy przypisać to samo znaczenie.

- Przekonującym argumentem jest również argument „językowy” oraz odwołujący się do zmian w treści projektu ustawy. Zgadzam się z twierdzeniem, że jest to argument przesądzający konieczność rozdzielenia pojęcia produktu ubezpieczeniowego od pojęcia umowy ubezpieczenia w kontekście IPID.

W mojej opinii za produkt ubezpieczeniowy należy zatem uznać postanowienia OWU lub innych wzorców umownych w rozumieniu art. 384 k.c. lub „szablonów”, klauzul i postanowień dodatkowych, które mają lub mogą mieć standardowo (tj. nie wymagając negocjacji pomiędzy stronami) zastosowanie do danego rodzaju umów ubezpieczenia i w sposób kompleksowy regulują stosunek ubezpieczenia czy też ramy, w jakich może zostać on ukształtowany.

Poza powyższymi argumentami przemawiającymi przeciwko utożsamianiu produktu ubezpieczeniowego i umowy ubezpieczenia istnieja jednak również inne ${ }^{43}$ argumenty, które można wywieść zarówno z treści przepisów prawa, jak i dokumentów wydanych przez ElOPA. Jednakże z uwagi na fakt, iż są one również związane z konkretnymi szczegółowymi zagadnieniami istotnymi dla praktyki, te dodatkowe argumenty poruszam w poszczególnych podrozdziałach rozdziału 3 niniejszego artykułu.

\section{Próba rozstrzygnięcia problemów istotnych z punktu widzenia praktyki}

W tym miejscu przejdę do omówienia problemów istotnych z punktu widzenia praktyki, wymienionych we Wprowadzeniu niniejszego artykułu.

\subsection{Treść IPID a postanowienia umowy ubezpieczenia}

Pierwszym problemem wymagającym rozstrzygnięcia jest odpowiedź na pytanie: czy i w jakim stopniu IPID powinien odzwierciedlać treść umowy ubezpieczenia, będąca pochodną uzgodnień pomiędzy stronami, nie zaś tylko postanowienia wzorca umownego mającego zastosowanie do umowy? Wprawdzie, jak już wskazywałem powyżej, doktryna generalnie stoi na stanowisku (które to stanowisko podzielam), iż produktu ubezpieczeniowego nie można utożsamiać z konkretną umową ubezpieczenia i jej „zindywidualizowanymi” postanowieniami. Niemniej jednak należy

43. Jak się wydaje - dotychczas nieprzytaczane albo niewystarczająco podkreślane przez doktrynę. 
mimo wszystko postawić to pytanie (oraz związane z nim pytania szczegółowe) w kontekście brzmienia niektórych przepisów odnoszących się do IPID, które przytaczam poniżej.

Mamy tutaj do czynienia z następującymi wạtpliwościami, które wymagają rozstrzygnięcia:

1) Czy IPID powinien odzwierciedlać postanowienia umowy ubezpieczenia, które siłą rzeczy będa zawsze „indywidualizowane” w umowie ubezpieczenia - jak np. wysokość składki, terminy jej zapłaty, wskazanie okresu ubezpieczenia (przez wskazanie konkretnych dat etc.)?

Watpliwości w tym zakresie moga pojawić się w szczególności w kontekście tego, że zgodnie z Rozporządzeniem IPID ustandaryzowany dokument ma wskazywać m.in. „Jak i kiedy należy opłacać składki?” oraz „Kiedy rozpoczyna się i kończy ochrona ubezpieczeniowa?” (art. 4 pkt 4 lit. g) oraz h) J. Jednocześnie w art. 6 ust. 1 lit. h) oraz i] Rozporządzenia IPID wskazano, że w tych sekcjach należy umieścić informacje, o których mowa w - odpowiednio - art. 20 ust. 8 lit. c) oraz h] IDD. 0 ile jeszcze art. 20 ust. 8 pkt c] IDD wymienia „tryb opłacania składek i okresy płatności” (co niekoniecznie samo w sobie wskazuje na konieczność „indywidualizacji” informacji), o tyle art. 20 ust. 8 lit. h) wskazuje na „czas trwania umowy, łącznie z datą rozpoczęcia i zakończenia umowy”, co sugerowałoby wyraźnie potrzebę takiej „indywidualizacji”44.

2) Czy IPID powinien odzwierciedlać dokonywany przez klienta wybór konkretnego zakresu ubezpieczenia spośród opcji, wariantów etc. dostępnych „standardowo” w ramach produktu? Wạtpliwości w tym zakresie moga pojawić się na gruncie art. 6 ust. 1 lit. b) i c) Rozporzadzenia IPID oraz art. 20 ust. 8 lit. b) IDD, do którego powyższe przepisy Rozporządzenia się odwołuja. Zgodnie z tymi przepisami IPID (w sekcji Co jest przedmiotem ubezpieczenia? powinien zawierać m.in. „krótki opis ochrony ubezpieczeniowej, obejmujacy główne rodzaje ubezpieczanego ryzyka” oraz „sumę ubezpieczenia” ${ }^{45}$. Wskazanie na „ubezpieczone ryzyka” sugeruje, że IPID powinien określać konkretny zakres ubezpieczenia, ustalony w ramach umowy, która ma zostać zawarta. Podobnie - pomijając produkty ubezpieczeniowe, w których standardowo obowiązuje zawsze taka sama suma ubezpieczenia bez możliwości ustalania jej wysokości w większości produktów ubezpieczeniowych suma ubezpieczenia będzie pochodną ustaleń pomiędzy stronami (lub np. wartości konkretnego przedmiotu ubezpieczenia).

3) W końcu - czy IPID powinien uwzględniać postanowienia szczególne, stanowiące odstępstwo od standardowego kształtu produktu (np. postanowienia szczególne w stosunku do OWU)? Ma to znaczenie w szczególności w kontekście dystrybucji ubezpieczeń w kanale brokerskim, gdzie takie odstępstwa są raczej standardem (chociażby w postaci tzw. „klauzul brokerskich”]. Rozstrzygnięcie problemu omawianego w niniejszym podrozdziale będzie w gruncie rzeczy pochodną rozstrzygnięcia problemu dotyczącego relacji pomiędzy pojęciem produktu ubezpieczeniowego a pojęciem umowy ubezpieczenia. Kwestię tę opisałem szczegółowo w podrozdziale 2.2 niniejszego artykułu, opowiadając się za stanowiskiem, zgodnie z którym pojęcia te nie są tożsame, a produkt ubezpieczeniowy oznacza określony typ umów ubezpieczenia i potencjalny zakres ochrony, nie zaś konkretną umowę ubezpieczenia.

Istnieją jednak również inne argumenty za przyjęciem tego poglądu - szczególnie istotne w kontekście zagadnienia rozpatrywanego w niniejszym podrozdziale:

44. Art. 8 ust. 6 pkt 8 u.d.u., stanowiący odpowiednik tego przepisu IDD, wskazuje na „okres trwania umowy ubezpieczenia lub umowy gwarancji ubezpieczeniowej, w tym dzień rozpoczęcia i zakończenia ich obowiązywania". Pomimo odmienności użytych sformułowań mamy zatem do czynienia z analogiczną wątpliwościa.

45. Analogiczne brzmienie ma art. 8 ust. 6 pkt 2 u.d.u., który stanowi odpowiednik art. 20 ust. 8 lit. b) IDD. 
- Analogiczne stanowisko wyraziła również EIOPA w dokumentach opisanych w rozdziale 1, które w praktyce mają fundamentalne znaczenie dla interpretacji przepisów Rozporządzenia IPID. EIOPA uznaje bowiem, że IPID jest dokumentem „przedumownym” i nie zastępuje uzgodnień i warunków wynikających z polisy (tj. umowy ubezpieczenia), a jakakolwiek „personalizacja” odnosząca się do klienta będzie dokonywana w drodze polisy, nie zaś IPID ${ }^{46}$.

- 0 ile stanowisko EIOPA nie znalazło wyraźnego odzwierciedlenia w treści Rozporządzenia IPID i w tym kontekście nie możemy mówić o argumencie opartym na treści przepisów, o tyle takich argumentów dostarcza już treść Rozporządzenia 2017/2358. Otóż, zgodnie z art. 3 ust. 3 tego rozporządzenia „Za tworzenie nie uznaje się personalizacji i dostosowywania istniejących produktów ubezpieczeniowych w kontekście działalności w zakresie dystrybucji ubezpieczeń dla indywidualnych klientów ani też opracowywania dostosowanych do potrzeb umów na wniosek pojedynczego klienta" ${ }^{\prime \prime}$. Oznacza to, że etap tworzenia produktu ubezpieczeniowego siła rzeczy nie obejmuje żadnych ustaleń zapadających pomiędzy stronami, dotyczących konkretnej umowy ubezpieczenia, która ma zostać zawarta. Co za tym idzie - takie ustalenia nie są elementem produktu ubezpieczeniowego.

W konsekwencji - IPID nie powinien odzwierciedlać indywidualnych uzgodnień pomiędzy stronami przyszłej umowy, bez względu na to, o której kategorii wskazanej w pkt 1 do 3 powyżej mówimy. Jeśli zatem chodzi o informacje o tym „Jak i kiedy należy opłacać składki?” oraz „Kiedy rozpoczyna się i kończy ochrona ubezpieczeniowa?" - IPID powinien opisywać wyłącznie ogólne rozwiązania przyjęte w ramach danego produktu (np. „składka może być opłacona jednorazowo lub ratalnie”, „umowa ubezpieczenia jest zawierana na okres 12 miesięcy”].

Kwestia ta - przynajmniej w kontekście zagadnień, o których mowa w pkt 1 i 2 powyżej - zdaje się nie wywoływać też wątpliwości w doktrynie ${ }^{48}$. Więcej kontrowersji wywołuje problem opisany w pkt 3 powyżej. Przykładowo, Łukasz Zoń w kontekście umów negocjowanych przez brokerów wyraża poglad, iż „w praktyce brokerskiej może okazać się tak, że każda zawierana umowa jest odrębnym produktem"49. Przywołany autor staje się w ten sposób pośrednio wyrazicielem pogladu, jakoby w kanale brokerskim ustalanie kształtu produktu odbywało się każdorazowo przy zawieraniu konkretnej umowy ubezpieczenia ${ }^{50}$. Inni autorzy z kolei opowiadają się za tym, że IPID

46. „IPID is a pre-contractual document and does not replace policy terms and conditions, which will be provided to customers in addition to the IPID. Any customer personalisation will be done via the policy terms and conditions, not the IPID" (Draft implementing technical standards ..., s. 4; Final Report on Consultation Paper..., s. 4); "The IPID will not be a personalised document. Instead the Level 1 IDD requires That IPID sets out the main characteristics of the product" (Final Report on Consultation Paper ..., s. 87).

47. Regulacja ta jest przywoływana przez B. Mrozowską-Bartkiewicz oraz A. Wnęk (zob. B. Mrozowska-Bartkiewicz, A. Wnęk, op. cit., s. 81), aczkolwiek nie w kontekście zagadnień związanych z IPID, a w kontekście systemu zarządzania produktem i określenia, kto jest twórca produktu.

48. Zob. stanowiska drugiej grupy autorów omówione w podrozdziale 2.2; Odmiennie M. Ziemiak, który wyraźnie wskazuje na konieczność indywidualizacji IPID w kontekście terminów płatności składki i sumy ubezpieczenia (zob. M. Ziemiak, op. cit., s. 109).

49. Ł. Zoń, Działalność brokerska po implementacji dyrektywy w sprawie dystrybucji ubezpieczeń - uwagi praktyczne, „Prawo Asekuracyjne” 2017, nr 2, s. 6.

50. Analogiczne stanowisko zdają się zajmować również autorzy projektu u.d.u., którzy w uzasadnieniu do projektu ustawy wskazali: „W polskim systemie prawnym produkty ubezpieczeniowe tworzone są z reguły przez zakłady ubezpieczeń, jednakże pośrednik ubezpieczeniowy w trakcie negocjacji umowy może mieć, w określonych okolicznościach, wpływ na kształt produktu, jak również na warunki ubezpieczenia. W związku 
nie powinien uwzględniać treści wynegocjowanych odstępstw od standardu, uznając za wystarczające przekazanie przez pośrednika informacji o różnicach pomiędzy zawartą umową ubezpieczenia a treścią OWU (art. 812 § 8 k.c.) lub rekomendacji brokerskiej ${ }^{51}$. Jednakże niektórzy z nich wskazujaj jednocześnie na to, że kwestia ta rodzi watpliwości ${ }^{52}$. Stanowiska EIOPA oraz treść art. 3 ust. 3 Rozporządzenia 2017/2358 takie wạtpliwości w mojej opinii rozwiewa.

Mimo iż powyższe argumenty przemawiają za tym, że IPID nie powinien zawierać odniesienia do „zindywidualizowanych" postanowień umowy ubezpieczenia, na pewno nie można też twierdzić, że kwestia ta pozostaje poza jakąkolwiek wạtpliwością - w szczególności w kontekście art. 20 ust. 8 lit. c) oraz h] IDD, do których odwołuje się art. 6 ust. 1 lit. h) oraz i) Rozporządzenia IPID. Ponadto, gdyby jakiś twórca produktu zdecydował się na opracowanie IPID „zindywidualizowanego" 53 , to trudno sobie wyobrazić sytuację, w której organ nadzoru zgłaszałby zastrzeżenia do takiego podejścia. ${ }^{54}$

\subsection{Kto sporządza IPID? (Kto jest twórcą produktu?)}

Z kwestią opisaną w podrozdziale 3.1 niniejszego artykułu związany jest inny problem - a mianowicie: kto jest twórca produktu odpowiedzialnym za opracowanie IPID, w szczególności przy dystrybucji w kanale brokerskim?

Jak już wskazano powyżej, negocjacji warunków umowy ubezpieczenia nie można uznać za etap tworzenia produktu. W konsekwencji twórcą produktu (a zatem podmiotem odpowiedzialnym za opracowanie IPID] będzie w praktyce zawsze zakład ubezpieczeń, nie pośrednik ubezpieczeniowy. Potwierdza to treść art. 3 ust. 1 i 2 Rozporzadzenia 2017/2358, zgodnie z którymi:

„1. Do celów art. 25 ust. 1 dyrektywy (UE) 2016/97 ${ }^{55}$ pośredników ubezpieczeniowych uznaje się za twórców w przypadkach, w których z całościowej analizy ich działalności wynika, że pełnia oni decyzyjną rolę w tworzeniu i opracowywaniu produktu ubezpieczeniowego przeznaczonego na dany rynek.

2. Przyjmuje się, że pośrednik ubezpieczeniowy pełni decyzyjną rolę, zwłaszcza gdy samodzielnie określa on najważniejsze cechy i główne elementy produktu ubezpieczeniowego, w tym zakres ubezpieczenia, cenę, koszty, ryzyko, rynek docelowy i prawa do odszkodowania i gwarancji,

z powyższym zasadnym wydaje się uznanie za twórcę produktu ubezpieczeniowego nie tylko zakład ubezpieczeń, ale również brokera ubezpieczeniowego oraz agenta ubezpieczeniowego." (Druk Sejmu VIII Kadencji nr 1781 - uzasadnienie; dostępny na stronie http://www.sejm.gov.pl/Sejm8.nsf/druk.xsp?nr=1781 [dostęp: 8.05.2019]]). Jednak uzasadnienie to nie może stanowić, w mojej opinii, przesłanki decydującej o rozumieniu pojęcia produktu ubezpieczeniowego, przede wszystkim z uwagi na cytowaną powyżej treść Rozporządzenia 2017/2358.

51. Tak np. M. Orlicki, op. cit., s. 19; A. Urbańczyk, op. cit. Co ciekawe, poglad taki reprezentuje również M. Ziemiak (M. Ziemiak, op. cit., s. 99-100), który wszak generalnie opowiada się za tym, że IPID powinien odzwierciedlać treść umowy ubezpieczenia.

52. Tak np. A. Urbańczyk, op. cit.

53. Co oczywiście wymagałoby odpowiednich rozwiązań technicznych i organizacyjnych, w szczególności jeśli dystrybucja produktu nie byłaby prowadzona bezpośrednio przez twórcę produktu.

54. Siła rzeczy informacja przedstawiana klientowi byłaby bowiem jeszcze bardziej adekwatna i precyzyjna niż "ogólna" informacja o produkcie.

55. Wprawdzie w przepisie tym ustawodawca odwołał się do art. 25 ust. 1 IDD dotyczącego systemu zarządzania i nadzoru nad produktem, jednakże - jak wskazałem w podrozdziale 2.2 - pojęcie produktu ubezpieczeniowego na gruncie IDD należy rozumieć w sposób jednolity, bez względu na kontekst, w którym jest używane. 
które nie są znacząco modyfikowane przez zakład ubezpieczeń zapewniający ochronę ubezpieczeniową z tytułu produktu ubezpieczeniowego."

Przesłanką do uznania pośrednika za twórcę produktu jest zatem jego decyzyjna rola w tworzeniu produktu. Nawet w kanale brokerskim, jeśli mamy do czynienia z wynegocjowanymi przez brokera bardzo daleko idącymi zmianami w stosunku do standardowego produktu ubezpieczyciela, wciąż twórca produktu (i podmiotem odpowiedzialnym za opracowanie IPID) pozostaje ubezpieczyciel. Jak już wskazano w podrozdziale 3.1 powyżej, IPID nie powinien odnosić się do postanowień odzwierciedlajacych indywidualne ustalenia stron, a jedynie obrazować standardowy kształt produktu.

Jedynie w sytuacji, w której to pośrednik ubezpieczeniowy opracowuje produkt „od zera”, pośrednik jest twórcą produktu. W praktyce jednak, nawet jeśli broker opracowuje samodzielnie unikalny program ubezpieczeniowy dla konkretnego klienta i poszukuje na rynku ochrony ubezpieczeniowej w oparciu o warunki ubezpieczenia przez siebie stworzone, to powstaje pytanie, czy broker jest w takim przypadku twórca produktu? Wydaje się, że tak nie jest. Po pierwsze bowiem - broker nie decyduje np. o cenie (składce), po drugie (co ważniejsze) - programu opracowanego z myślą o konkretnym kliencie (nie zaś grupie klientów docelowych) nie można raczej nazwać produktem. Trudno tutaj bowiem mówić o jakimkolwiek „rynku” (w rozumieniu art. 3 ust. 1 Rozporządzenia 2017/2358]. Co więcej - w takiej sytuacji można nawet uznać, że nie zachodzi konieczność opracowania IPID (zob. uwagi w podrozdziale 3.3 poniżej).

Inaczej przedstawia się sytuacja, w której broker opracowuje program ubezpieczeniowy przeznaczony dla określonej grupy klientów (np. członków stowarzyszenia, klientów funduszu leasingowego etc.]. Jednak nawet w takim przypadku - jak się wydaje - broker i tak będzie co najwyżej współtwórca produktu, to ubezpieczyciel bowiem decyduje o wysokości składki ${ }^{56}$. Tylko w przypadku, w którym broker decydowałby również o wysokości składki w takim programie, można by go uznać za „samodzielnego” twórcę produktu. Zgodnie z art. 3 ust. 4 w/w rozporządzenia, konsekwencją uznania, że pośrednik jest współtwórcą produktu, jest konieczność zawarcia pomiędzy ubezpieczycielem a pośrednikiem pisemnej umowy, „w której określa się szczegółowe warunki ich współpracy zgodnie z wymogami dla twórców, o których mowa w art. 25 ust. 1 dyrektywy (UE) 2016/97, procedury, które umożliwiają im w zgodny sposób określić rynek docelowy, oraz pełnione przez nich role w procesie zatwierdzania produktu." Umowa ta powinna zatem wskazywać, czyim zadaniem jest opracowanie IPID.

\subsection{Umowy ubezpieczenia, przed zawarciem których nie ma obowiązku przekazywania IPID}

Kolejnym problemem istotnym dla praktyki jest odpowiedź na pytanie: czy obowiązek przekazania IPID będzie zachodził zawsze, czy też występują sytuacje, w których przekazanie IPID nie będzie konieczne?

56. Jako przykład sytuacji, w której pośrednik ubezpieczeniowy jest współtwórca produktu, można podać również przypadek, gdy bank będący agentem ustala z zakładem ubezpieczeń warunki programu dla swoich klientów. Taki przykład podają B. Mrozowska-Bartkiewicz i A. Wnęk (zob. B. Mrozowska-Bartkiewicz i A. Wnęk, op. cit., s. 87). Jednak w mojej opinii uznanie banku za współtwórcę produktu zależy od stopnia jego faktycznego wpływu na warunki programu. Jeśli - jak piszą autorki - bank „w zapytaniu ofertowym określa przedmiot i zakres ubezpieczenia", a oferta zakładu ubezpieczeń jest oparta na standardowych produktach ubezpieczyciela, to moim zdaniem banku nie można uznać za współtwórcę produktu. 
Jedną z odpowiedzi znajdziemy wprost z przepisach. Zgodnie bowiem z art. 9 ust. 8 u.d.u., określone obowiązki informacyjne (w tym obowiązek przekazania IPID) nie mają zastosowania w przypadku, gdy umowa ubezpieczenia obejmuje duże ryzyka w rozumieniu art. 3 ust. 1 pkt 6 u.dz.u.r.5?

Wydaje się jednak, że nie jest to jedyny przypadek, w którym IPID nie musi być przekazany przed zawarciem umowy ubezpieczenia (oraz w którym nie musi być w ogóle sporządzony). Jak już wskazywałem w podrozdziale 3.2 powyżej - jeśli umowa ubezpieczenia, która ma być zawarta $\underline{z}$ konkretnym klientem, nie jest w ogóle oparta na standardowym produkcie ubezpieczyciela (z ewentualnymi modyfikacjami), a jej treść jest ustalana „od podstaw” (np. w oparciu o założenia indywidualnego programu przygotowanego przez brokera], to w ogóle nie mamy do czynienia z produktem ubezpieczeniowym w rozumieniu przepisów. Produkt jest bowiem czymś powtarzalnym. Z produktem jest immanentnie związane pojęcie grupy docelowej klientów bądź rynku docelowego. W sytuacji gdy taka umowa ubezpieczenia ma dotyczyć konkretnego klienta, nie możemy mówić zatem o produkcie. W konsekwencji - w takim przypadku IPID w ogóle nie powinien mieć zastosowania ${ }^{58}$.

\subsection{IPID a ubezpieczenia pakietowe}

Jednym z najistotniejszych problemów z punktu widzenia praktyki rynkowej jest pytanie, do czego powinien odnosić się IPID w przypadku ubezpieczeń pakietowych. Przez ubezpieczenia pakietowe rozumiem umowy ubezpieczenia odnoszące się do jednego przedmiotu ubezpieczenia ${ }^{59}$, obejmujące różne rodzaje ryzyk, należących do różnych grup ubezpieczeń w rozumieniu załącznika do u. dz.u.r. Chodzi o ryzyka, które w praktyce rynkowej mogą być ubezpieczane osobno, ale w ubezpieczeniu pakietowym są obejmowane jedną umową ubezpieczenia ${ }^{60}$ i potwierdzane jedna polisą. Przykładem są tutaj ubezpieczenia komunikacyjne obejmujące ubezpieczenie obowiązkowe OC posiadaczy pojazdów mechanicznych (OC ppm), autocasco (AC), assistance, ubezpieczenie następstw nieszczęśliwych wypadków (NNW), ubezpieczenie ochrony prawnej czy też ubezpieczenie Zielonej Karty. Innym przykładem są ubezpieczenia mieszkań. Jeżeli jako składowe pakietu rozumiemy poszczególne rodzaje ubezpieczeń (OC ppm, AC, NNW etc.), to powstaje pytanie, czy produktem ubezpieczeniowym jest cały pakiet czy też jego składowe są osobnymi produktami.

57. Duże ryzyka - ryzyka, o których mowa w dziale II załącznika do ustawy:

a) w grupach 4-7, 11 i 12 ,

b) w grupach 14 i 15 - w przypadku gdy ubezpieczający wykonuje działalność gospodarczą lub wolny zawód, a ryzyko wiąże się z tą działalnością,

c) w grupach 3, 8, 9, 10, 13 i 16 - w przypadku gdy ubezpieczający przekracza co najmniej dwa z następujących progów w roku obrotowym:

- $\quad$ sumę aktywów bilansu w wysokości równowartości w złotych 6,2 mln euro,

- $\quad$ łączne przychody netto ze sprzedaży towarów i usług oraz operacji finansowych w wysokości równowartości w złotych 12,8 mln euro,

- $\quad$ średnioroczne zatrudnienie w przeliczeniu na pełne etaty w liczbie 250 osób.

58. Na takim stanowisku stoi też część przedstawicieli doktryny - zob. np. A. Urbańczyk, op. cit.; A. Przybysz, T. Kwieciński, op. cit.; J. Nowak, op. cit., pkt 56.

59. W rozumieniu materialnego "substratu” ochrony ubezpieczeniowej.

60. Abstrahuję tutaj od rozważań, czy w ujęciu prawnym jest to jedna czy wiele umów ubezpieczenia. 
Analiza przepisów nie pozwala na udzielenie jednoznacznej odpowiedzi na pytanie postawione powyżej. Jedynie art. 24 ust. 5 IDD ${ }^{61}$ stanowi: „Niniejszy artykuł nie uniemożliwia dystrybucji produktów ubezpieczeniowych zapewniających ochronę przed różnymi rodzajami ryzyka (polis ubezpieczeniowych od wielu rodzajów ryzyka]". Jak się wydaje, ustawodawca europejski dopuszcza zatem sytuację, w której jeden produkt ubezpieczeniowy obejmuje różne rodzaje ryzyka. Z drugiej jednak strony, powstaje pytanie, czy można przywiązywać do tego przepisu decydującą wagę w kontekście opisywanych już powyżej mankamentów terminologicznych tej Dyrektywy. Inne przepisy - a w szczególności Rozporządzenie IPID - nie zawieraja żadnych regulacji w tej kwestii. Jedynie w Rozporządzeniu IPID, w art. 4 ust. 2, ustawodawca użył sformułowania: „Informacji o ewentualnych klauzulach dodatkowych i fakultatywnej ochronie ubezpieczeniowej nie poprzedza się znakiem parafki, krzyżyka ani wykrzyknikiem" ${ }^{\text {. }}$. Ma to w mojej ocenie pewne znaczenie w kontekście rozpatrywanej kwestii, o czym mowa szerzej poniżej.

Jednakże z kolei treść zarówno Draft Implementing Technical Standards ..., jak i - w szerszym jeszcze zakresie - Final Report on Consultation Paper... wskazuje na to, że ElOPA rozważała kwestię IPID w ubezpieczeniach określanych przez siebie jako multi-risk. Pomimo faktu, iż szereg podmiotów biorących udział w konsultacjach społecznych krytykowało przyjęte przez EIOPA rozwiązanie, europejski organ nadzoru zdecydował się na przyjęcie wariantu, w którym jeden IPID powinien mieć zastosowanie do jednej polisy obejmującej wiele ryzyk.

Wracając do opisanych w podrozdziale 2.2 rozważań doktryny dotyczących pojęcia produktu ubezpieczeniowego, należy wskazać, że część autorów - akceptując definicję przyjętą w Rekomendacjach KNF - stoi na stanowisku, że produkt jest to typ umów ubezpieczenia wyodrębniony ze względu na stosowane do nich $\mathrm{OWU}^{63}$. Takie podejście prowadziłoby do uznania, że produktem ubezpieczeniowym jest albo cały pakiet, albo też jego składowe - w zależności od tego, jaką konstrukcję (jedno czy osobne OWU na pakiet) stosuje dany zakład ubezpieczeń. Z drugiej jednak strony, definicja ta nie była przyjmowana przez tych autorów w kontekście rozważań, czy IPID powinien mieć zastosowanie do całego pakietu, czy też do każdej z jego składowych.

Większość przedstawicieli doktryny, którzy wypowiadali się na temat przedmiotowej kwestii, przyjmuje - w ślad za stanowiskiem EIOPA - że IPID powinien mieć zastosowanie do całego pakietu $^{64}$. Jak się wydaje, jedynie Marcin Orlicki wyraźnie opowiada się za rozwiązaniem, w którym każdy element pakietu powinien znaleźć odzwierciedlenie w osobnym IPID ${ }^{65}$.

61. Który nie znalazł swojego odpowiednika w u.d.u. (art. 24 IDD dotyczy „sprzedaży krzyżowej”, czyli materii uregulowanej w art. 10 u.d.u.].

62. Podaję w tym miejscu treść fragmentu angielskiej wersji Rozporządzenia: „Information about add-ons and optional covers shall not be preceded by ticks, crosses or exclamation marks".

63. Tak M. Orlicki, op. cit., s. 16 (jednak patrz przypis nr 68 poniżej); A. Przybysz, T. Kwieciński, op. cit.

64. Tak np. J. Nowak, op. cit., pkt 54; P. Stykowski, Komentarz do: Ustandaryzowany dokument dla ubezpieczeń „pakietowych” - jeden czy wiele?, „Dziennik Ubezpieczeniowy” 23.05.2018.

65. M. Orlicki, op. cit., s. 22. Autor ten pisze: „Zwykle ogólne warunki ubezpieczenia określają zasady kontraktowe odnoszące się do jednego produktu ubezpieczeniowego. Odpowiada im wtedy jeden ustandaryzowany dokument. Może się jednak zdarzyć, że w jednych ogólnych warunkach ubezpieczenia zamieszczono zasady kontraktowe odnoszące się do wielu produktów ubezpieczeniowych (pakietu produktów). W takim przypadku należy przygotować odrębne ustandaryzowane dokumenty odnoszące się do każdego z produktów. Oczywiście fakt ewentualnego koniecznego ich połączenia w ramach pakietu powinien zostać uwzględniony $w$ treści każdego z ustandaryzowanych dokumentów." Należy przy okazji w tym miejscu zwrócić uwagę na pewną wewnętrzną sprzeczność z poglądem wyrażonym w tej samej publikacji przez M. Orlickiego, zgodnie z którym 
W mojej ocenie jednak stanowisko EIOPA w tej kwestii nie jest tak jednoznaczne, jakby mogło się wydawać. W rzeczonych dokumentach EIOPA określa bowiem w sposób niejasny (i tak naprawdę czasem wewnętrznie sprzeczny), co należy rozumieć przez multi-risk insurance. Z jednej strony EIOPA rozróżnia multi-risk insurance oraz add-ons i optional covers. Z drugiej strony - niejednokrotnie wskazuje, że powyższe kategorie pojęciowe zostały potraktowane w sposób jednolity w kontekście uwag podmiotów zgłaszających swoje zastrzeżenia na etapie konsultacji (w praktyce chodziło o zwiększenia maksymalnej objętości dokumentu do 3 stron A4). Jednakże w samym projekcie Rozporządzenia IPID zgłoszonym przez EIOPA znalazły się już jedynie odniesienia do add-ons i optional covers (bez jakichkolwiek odniesień do multi-risk insurance ) ${ }^{66}$. Takie też wyrażenia pozostały w finalnej wersji Rozporządzenia IPID. Te sformułowania zostały w mojej opinii dosyć wiernie (jeśli chodzi o ich istotę) przetłumaczone w polskiej wersji Rozporządzenia IPID („klauzule dodatkowe” i „fakultatywna ochrona ubezpieczeniowa”] ${ }^{6}$. Z analizy dokumentów EIOPA wynika również, że nawet tam, gdzie EIOPA ma na myśli faktycznie multi-risk insurance, nie zaś add-ons i optional covers, to rozumie przez to sytuację, w której dany pakiet zawiera ryzyko (ubezpieczenie) obligatoryjne dla klienta, natomiast inne ryzyka (ubezpieczenia) są wyłącznie fakultatywnym uzupełnieniem ubezpieczenia głównego ${ }^{68}$. Niezależnie od powyższego ElOPA, odnosząc się do multi-risk insurance, definiuje takie ubezpieczenia przez pryzmat kryterium objęcia wielu ryzyk ochroną na podstawie ,jednej polisy”. W w/w dokumencie uzgodnieniowym kierowanym do konsultacji rynkowych EIOPA wyraziła obawy związane z sytuacja, w której do pakietu miałby odnosić się jeden ustandaryzowany dokument. Zdaniem EIOPA klienci mogliby wtedy przyjąć nieuzasadnione założenie, że np. możliwe byłoby anulowanie przez nich ochrony odrębnie w stosunku do każdego z ryzyk/ubezpieczeń. Wszystko to potwierdza, że stanowisko ElOPA dotyczące jednego IPID dla pakietu jest m.in. pochodną założenia, że jedna polisa jest równoznaczna z jedną umową ubezpieczenia (w ujęciu prawnym), która to umowa może obejmować jedno lub wiele (dodatkowych) ryzyk. Tymczasem na gruncie prawa polskiego co do zasady w ramach pakietu będziemy mieli z reguły do czynienia z osobnymi umowami ubezpieczenia ${ }^{69}$. W najprostszym przykładzie: jeśli klient kupił ubezpieczenie komunikacyjne obejmujące OC ppm, AC oraz NNW, to byt prawny tych trzech ubezpieczeń jest właściwie od siebie zupełnie niezależny loczywiście poza sytuacjami, które moga być wspólnym mianownikiem do zakończenia udzielania ochrony w ramach wszystkich z nich]. Rozróżnienie pomiędzy multi-risk insurance oraz add-ons i optional covers w kontekście stanowiska EIOPA i treści przepisów nie jest łatwe. Przez add-ons oraz optional covers (do których odnosi się Rozporządzenie IPID) należy w mojej opinii rozumieć generalnie to, co zostało ujęte w polskiej wersji Rozporządzenia IPID. Co za tym idzie - chodzi o klauzule dodatkowe oraz ochronę fakultatywna, które (siłą rzeczy) mogą być jedynie uzupełnieniem

produkt ubezpieczeniowy jest identyfikowany przez odrębne OWU (zob. M. Orlicki, op. cit., s. 16). Przytoczony tutaj cytat zdaje się wskazywać, iż autor ten uważa jednak, że jedne OWU niekoniecznie świadczą o tym, że mamy do czynienia z jednym produktem. M. Orlicki nie odnosi się też w żaden sposób do stanowiska ElOPA.

66. Na fakt, iż stanowisko EIOPA dotyczące ubezpieczeń multi-risk nie znalazło wyraźnego odzwierciedlenia w treści Rozporządzenia IPID zwraca też uwagę J. Nowak (zob. J. Nowak, op. cit.).

67. Chodzi 0 art. 4 ust. 2 Rozporządzenia IPID.

68. Wskazuje na to chociażby sformułowanie użyte przy opisie rozważanych przez ElOPA wariantów postępowania: „Additional cover offered with the primary cover included in the IPID of the primary product”.

69. Świadomie nie rozwijam tutaj tego wątku ani nie przytaczam prawnego uzasadnienia, bo byłyby ono zbyt obszerne. 
Ustandaryzowane dokumenty zawierające informacje o produkcie ubezpieczeniowym...

do ubezpieczenia podstawowego oraz które - zważywszy na konstrukcję produktu - nie mogłyby być właściwie objęte ochroną w ramach odrębnej umowy polisy. Można najlepiej to wyjaśnić na przykładzie ubezpieczenia assistance. Jeśli ubezpieczenie assistance stanowi rozszerzenie ubezpieczenia AC (opcja dodatkowa do AC, „funkcjonalnie” związana z AC - chociażby np. przez ten sam zakres zdarzeń ubezpieczeniowych), to jest to klauzula dodatkowa czy też ochrona fakultatywna (do ubezpieczenia podstawowego). Jeśli jednak takie ubezpieczenie assistance jest elementem samodzielnym (klient może je nabyć w ramach pakietu, nawet bez ubezpieczenia AC), to powinien go dotyczyć osobny IPID.

Podsumowując powyższe rozważania, w mojej opinii stosowanie osobnych IPID do poszczególnych składowych pakietów powinno mieć zastosowanie w tych przypadkach, w ramach których: 1) nie mamy do czynienia z ubezpieczeniem podstawowym oraz ubezpieczeniami (ryzykami) dodatkowymi - tj. umowa ubezpieczenia może być zawarta w odniesieniu do któregokolwiek z elementów pakietu;

2) każde ryzyko (ubezpieczenie) w sensie prawnym będzie stanowić odrębną umowę ubezpieczenia.

Jeden IPID powinien mieć zastosowanie jedynie w przypadku pakietów, w których mamy do czynienia z ubezpieczeniem podstawowym oraz ubezpieczeniami dodatkowymi (które można objąć umową pod warunkiem, że umowa obejmuje ubezpieczenie podstawowe], a jednocześnie w sensie prawnym mamy do czynienia z jedną umową. Przykładem może być tutaj ubezpieczenie NNW z podstawowym ubezpieczeniem na wypadek śmierci oraz ubezpieczeniami dodatkowymi (uszczerbek na zdrowiu, pobyt w szpitalu, niezdolność do pracy etc.). Nie ma w mojej opinii aksjologicznych podstaw do uznawania za jeden produkt ubezpieczeniowy (i co za tym idzie - stosowania jednego IPID) ubezpieczeń, które właściwie nie mają za sobą nic wspólnego?0, poza tym, że odnoszą się do tego samego ubezpieczonego lub przedmiotu ubezpieczenia. Ponadto ujęcie w jednym IPID informacji o tych wszystkich ubezpieczeniach w sposób w miarę pełny, a jednocześnie klarowny będzie w praktyce często niewykonalne.

Zaznaczam jednak, że omawiane zagadnienie jest kontrowersyjne. Bez względu na to, jakie podejście przyjmie dany zakład ubezpieczeń, będzie się ono nadawało do obrony w kontekście treści przepisów, a właściwie w kontekście braku przepisów wyjaśniających tę kwestię. 0 ile bowiem - jeśli chodzi o zagadnienia omawiane w podrozdziałach 3.1-3.3 niniejszego artykułu - argumentację można zasadniczo oprzeć na treści przepisów (lub dokumentów EIOPA), o tyle - jeśli chodzi o kwestię IPID w ubezpieczeniach pakietowych - argumenty mają charakter aksjologiczny. Przepisy Rozporządzenia IPID oraz wydane przez EIOPA regulacje soft-law, które mogłyby być pomocne przy rozstrzygnięciu omawianego tu problemu, posługują się z kolei żargonem ubezpieczeniowym $^{71}$ (multi-risk insurance oraz add-ons i optional covers), co sprawia, że wyciaganie na ich podstawie jednoznacznych wniosków jest właściwie niemożliwe.

W tym miejscu należy zaznaczyć, że rynek stosuje generalnie dwojakie podejście, jeśli chodzi o „technikę redakcyjna” OWU - tj. osobne OWU na każde z ubezpieczeń składających się na pakiet albo wspólne OWU dla wszystkich ubezpieczeń w ramach pakietu. Mamy za to do czynienia raczej z jednolitym podejściem rynku co do „pakietyzacji” tych ubezpieczeń w kontekście dystrybucji. Niezależnie bowiem od tego, czy dany ubezpieczyciel stosuje jedno OWU, czy wiele OWU

70. W kontekście interesu, który podlega ochronie, katalogu zdarzeń ubezpieczeniowych, wyłączeń odpowiedzialności, charakteru świadczenia etc.

71. Którego - paradoksalnie - nakazuje unikać samo Rozporządzenie IPID (art. 5 in fine). 
w odniesieniu do pakietu, klient może zawrzeć umowę ubezpieczenia obejmująca jedno bądź wiele z tych ubezpieczeń, która to umowa potwierdzana jest jedna polisa. Różnice sprowadzaja się ewentualnie do tego, czy zawarcie umowy w ramach określonego ubezpieczenia (bądź jego wariantu] jest lub nie jest uzależnione od wykupienia innego ubezpieczenia związanego z danym przedmiotem ubezpieczenia. To, czy klient (zawarłszy umowę w odniesieniu do kilku ubezpieczeń) otrzymuje jedno wspólne OWU czy też kilka OWU, jest zatem wyłącznie pochodną rozwiązania „technicznego” stosowanego przez danego ubezpieczyciela.

W konsekwencji, rynek ubezpieczeniowy podszedł do omawianego problemu na zasadzie „ile OWU - tyle IPID”. Ci ubezpieczyciele, którzy stosują osobne OWU do poszczególnych elementów pakietu - stosują osobne IPID. Natomiast ci, którzy stosują jedno OWU na pakiet - stosują również jeden IPID. W tym drugim przypadku (w przypadku pakietów komunikacyjnych) jedynie OC ppm (chociaż też nie zawsze) jest wyłączone do osobnego IPID. Nie trzeba chyba łłumaczyć, jakie powoduje to konsekwencje w kontekście możliwości porównania produktów poszczególnych ubezpieczycieli. Bez względu na to, co obiektywnie należałoby rozumieć przez produkt (tj. cały pakiet czy poszczególne składowe tego pakietu), takie zróżnicowane podejście oznacza, że klient otrzymuje sprzeczny przekaz co do tego, czym w ogóle jest produkt. Aby porównać produkty / składowe produktów dwóch ubezpieczycieli, którzy stosują odmienną „technikę redakcyjną” OWU, klient musiałby porównać - wspólny IPID jednego ubezpieczyciela z kilkoma osobnymi IPID drugiego ubezpieczyciela. Dodatkowo sprawę komplikuje fakt, że niejednokrotnie różne wariacje dotyczące zakresu ochrony w ramach danego ubezpieczenia (w szczególności AC) u jednego ubezpieczyciela będą stanowiły po prostu określone możliwe do wyboru opcje / warianty ochrony, opisane w jednym OWU, z kolei u innego - znajdą odzwierciedlenie w dedykowanych im osobnych OWU (różne OWU na różne warianty ochrony). Co więcej - to, co u jednego ubezpieczyciela będzie pewną opcją dodatkową rozszerzającą ochronę w ramach danego ubezpieczenia i w danym OWU (np. ubezpieczenie szyb / ochrona zniżek jako klauzula dodatkowa w ubezpieczeniu AC), u innego będzie osobnym ubezpieczeniem, z osobnymi dedykowanymi OWU. Oczywiście - w ślad za tymi różnicami w konstrukcji produktów (a właściwie - redakcji OWU z nimi związanych) idą różnice w filozofii redakcji IPID [czyli „osobne OWU = osobny IPID”).

Zgodnie z motywem 3 preambuły Rozporządzenia IPID podstawowym celem IPID jest „zapewnić klientom informacje o produkcie, które łatwo odczytać, zrozumieć i porównać". Omawiana powyżej niejednolitość podejścia rynku do kwestii IPID w ubezpieczeniach pakietowych sprawia, że powyższe założenie nie tylko nie jest realizowane, ale wręcz prowadzi do efektu dokładnie odwrotnego od zamierzonego przez ustawodawcę (przynajmniej w kontekście porównania pomiędzy produktami różnych ubezpieczycieli]. Co więcej - dzieje się tak w sytuacji, w której żadnemu zakładowi ubezpieczeń nie można zarzucić podejścia niezgodnego z przepisami.

\section{Podsumowanie}

Podsumowując powyższe rozważania, w mojej opinii:

1) brak wyraźnych regulacji prawnych oraz wypracowanych standardów rynkowych dotyczacych tego, co należy rozumieć przez produkt ubezpieczeniowy;

2) różnorodność podejścia rynku, jeżeli chodzi o: 
a) sposób konstruowania produktów ubezpieczeniowych (w kontekście „pakietyzacji”, „wariantowości" etc.);

b) przyjęta „technikę redakcyjna” OWU (jedno / wiele OWU na pakiet; opcja dodatkowa w ramach ubezpieczenia podstawowego vs. osobne ubezpieczenie);

sprawiają, że cel regulacji w postaci wprowadzenia ujednoliconych standardów dotyczących informowania o produkcie ubezpieczeniowym jest z góry skazany na niepowodzenie. Niestety, jest nawet gorzej, gdyż regulacja w praktyce przynosi efekt odwrotny do zamierzonego (czyli zapewnienia klientom informacji, które łatwo odczytać, zrozumieć i porównać]. Fakt, iż ustawodawca posługuje się w przepisach pojęciem niedefiniowanym, nie jest oczywiście problemem samym w sobie. Staje się jednak problemem w sytuacji, gdy nie mamy do czynienia z powszechnym i jednolitym rozumieniem tego pojęcia przez adresatów przepisów, a pojęcie to jest kluczowe dla ustalenia normy z tych przepisów wynikającej.

0 ile większość omawianych problemów można rozstrzygnąć, o tyle na kanwie każdego z nich wciąż pozostają mniejsze lub większe wạtpliwości. Jest to również pochodną nie tylko mankamentów regulacji w obszarze stosowanej siatki pojęciowej, ale również niespójności, a nawet wewnętrznych sprzeczności pomiędzy poszczególnymi aktami prawnymi oraz stanowiskiem ElOPA?2. Ponadto pojawia się pytanie o sens pewnych rozwiązań - jak np. obowiązku przekazania klientowi IPID w przypadku, w którym pośrednik (w warunkach polskich - broker) udziela rekomendacji. Nie ulega wạtpliwości, iż celem regulacji dotyczącej IPID było zwiększenie poziomu ochrony interesów klientów poprzez zapewnienie im dostępu do rzetelnej informacji o produkcie ubezpieczeniowym. Jak się jednak wydaje, zabrakło głębszej refleksji co do tego, w jaki sposób ten zamysł zrealizować.

W mojej opinii w niektórych obszarach istotnych z punktu widzenia praktyki (np. IPID w ubezpieczeniach pakietowych) istnieje pole do wydania rekomendacji przez KNF albo do ustalenia praktyk postępowania w drodze samoregulacji przez rynek. Spójność podejścia w obrębie rynku jest bowiem warunkiem koniecznym do tego, aby - przynajmniej w pewnej mierze - cel regulacji został osiagnięty.

\section{Wykaz źródeł}

Kamiński Ł., Pojęcie usługi i produktu w dystrybucji usług ubezpieczeniowych, [w:] Dystrybucja usług ubezpieczeniowych, Gnela B., Szaraniec M. [red.], Difin, Warszawa 2017.

Malinowska K., Pojęcie zarzqdzania produktem ubezpieczeniowym w świetle dyrektywy o dystrybucji ubezpieczeń i przepisów implementacyjnych, „Wiadomości Ubezpieczeniowe” 2017, nr 1.

Maśniak D., Czy test wymagań i potrzeb klienta to wniosek ubezpieczeniowy?, [w:] Dystrybucja usług ubezpieczeniowych, Gnela B., Szaraniec M. [red.], Difin, Warszawa 2017.

Maśniak D., Malinowska K., Czynności dystrybucyjne w nowym reżimie zawierania umów ubezpieczenia - wybrane aspekty implementacji dyrektywy nr 2016/97 w sprawie dystrybucji ubezpieczeń, „Prawo Asekuracyjne” 2017, nr 2.

72. Zob. uwagi w podrozdziale 3.1 odnośnie do przepisów IDD sugerujących konieczność „indywidualizacji” IPID w kontekście stanowiska EIOPA oraz przepisów Rozporządzenia 2017/2358. 
Mrozowska-Bartkiewicz B., Wnęk A., Pojęcie twórcy produktu ubezpieczeniowego w ustawie o dystrybucji ubezpieczeń, [w: ] Insurance Challenges of Anno Domini 2018, Malinowska K., Tarsiuk A. [red.], AIDA, Warszawa 2018.

Nawracała J., IPID-y, czyli o pseudostandaryzacji (cz. 1), „Miesięcznik Ubezpieczeniowy” 2018, nr 12. Nawracała J., IPID-y, czyli o pseudostandaryzacji (cz. 2), „Miesięcznik Ubezpieczeniowy” 2019, nr 1. Nowak J., [w]: Ustawa o dystrybucji ubezpieczeń. Komentarz, Czublun P. [red.], CH Beck, Warszawa 2018.

Orlicki M., Ustandaryzowany dokument według ustawy o dystrybucji ubezpieczeń - zasady tworzenia i znaczenie prawne, „Prawo Asekuracyjne” 2017, nr 4.

Przybysz A., Kwieciński T., [w:] Nowe zasady dystrybucji ubezpieczeń. Zagadnienia prawne, Pokrzywniak J. [red.], Wolters Kluwer, Warszawa 2018.

Więcko-Tułowiecka M., ElOPA’s Preparatory Guidelines on Product Oversight and Governance Arrangements by Insurance Undertakings and Insurance Distributors in the Context of Polish Recommendations on Product Management, „Prawo Asekuracyjne” 2018, nr 3.

Ziemba J., [w]: Ustawa o dystrybucji ubezpieczeń. Komentarz, Machulak P., Ziemba J. [red.], CH Beck, Warszawa 2018.

Ziemiak M., Informacja o produkcie ubezpieczeniowym i tzw. karta informacyjna produktu. Kilka uwag na tle artykułów 8 i 9 ustawy o dystrybucji ubezpieczeń, [w:] Insurance Challenges of Anno Domini 2018, Malinowska K., Tarsiuk A. [red.], AIDA, Warszawa 2018.

Zoń Ł., Działalność brokerska po implementacji dyrektywy w sprawie dystrybucji ubezpieczeń uwagi praktyczne, „Prawo Asekuracyjne” 2017, nr 2.

\section{Standardised insurance product information document. Possible interpretation in the context of „insurance product” term}

The Act on Insurance Distribution introduced a requirement for the insurance distributor to provide the customer with objective information on the insurance product prior to the conclusion of the insurance contract. In the case of Part II insurance, this information should be provided in the form of a standardized document. The aim of this article is to analyze selected practical problems related to the application of provisions on standardized documents containing information about the insurance product. The resolution of these problems will indeed derive from the interpretation of the term "insurance product”. Unfortunately, the regulations do not contain a definition of this term, which may lead to ambiguous conclusions in areas important for practice. The article discusses mainly the main doubts and possible ways of interpreting the regulations.

Key words: insurance distribution, standardised insurance product information document, IPID, insurance product.

JAKUB NAWRACAŁA - absolwent Uniwersytetu im. Adama Mickiewicza w Poznaniu, radca prawny specjalizujący się w obsłudze podmiotów sektora ubezpieczeniowego.

e-mail: jakub.nawracala@kancelaria-jn.pl 